\title{
Konflikty narodowo-etniczne w społecznościach pogranicza kulturowego w województwie podlaskim
}

Streszczenie: W artykule zostały przedstawione i omówione konflikty o charakterze narodowo-etnicznym zachodzące w ostatnich latach w województwie podlaskim. Autor wymienia szereg czynników wewnętrznych i zewnętrznych, które powodują występowanie na północno-wschodnim pograniczu Polski zwiększonej liczby sytuacji konfliktowych o podłoży etniczno-narodowym. Wskazuje, że pojawiające się konflikty nie oznaczają osłabienia pozycji mniejszości etnicznych i narodowych. Wiąże je ze wzrostem świadomości w zakresie obrony wartości rodzimych.

Słowa kluczowe: konflikt narodowy i etniczny, pogranicze, mniejszości narodowo-etniczne.

\section{Wprowadzenie}

Po g r a n i c z e określane jest jako teren graniczny, dwoisty terytorialnie, synonimicznie rozpatrywany jako teren stykowy bądź pomostowy (Kosiedowski i Słowiński, 2009, ss. 28-29). Wskazuje to na najbardziej powszechną definicję, gdyż odwołuje się do pierwszych, geograficznych skojarzeń z pojęciem - pogranicze jako przestrzeń pomiędzy, a więc obszary obrzeżne państw (Szczepański i Śliz, 2014, s. 52). Północno-wschodnie pogranicze Polski „jest krainą historyczno-geograficzną, która przez stulecia pełniła funkcję pogranicza zarówno politycznego, jak i narodowościowo-wyznaniowego oraz społeczno-kulturowego, gdzie dochodziło do przenikania etnosu polskiego, litewskiego, białoruskiego i ukraińskiego" (Barwiński, 2002, s. 281). Tereny te są również często nazywane pograniczem religijnym ze względu na mieszające się tu wpływy kultury zachodniej (łacińskiej) oraz wschodniej (prawosławnej, ruskiej) (Awramiuk-Godun, 2013, s. 63). Można więc analizować to pogranicze $w$ kontekście terytorialnym, treściowo-kulturowym, interakcyjnym i świadomościowym (Nikitorowicz, 1995). Mieszkający tu Polacy, Białorusini, 
Litwini, Ukraińcy, Rosjanie, Tatarzy, Czeczeni, katolicy, prawosławni, mniej liczni muzułmanie, a nawet protestanci tworzą niepowtarzalną mozaikę kontaktów międzykulturowych, co ma swoje odzwierciedlenie w aktywności mniejszości. Mniejszościowe stowarzyszenia, prasa, radio, inicjatywy czy imprezy kulturalne są najlepszym dowodem różnorodności kulturowej i etnicznej województwa. W ostatnich dekadach nastąpiło wyraźne zinstytucjonalizowanie zróżnicowania kulturowego i doprowadzenie do sytuacji, w której każda z mniejszości autochtonicznych ma trwałe miejsce w życiu lokalnej społeczności (Sadowski, 2019). Sąsiedztwo i interakcje, interpretacja historii, świadomość odrębności, pamięć przeżyć i losów społeczności historycznie odmiennych kulturowo coraz częściej prowadzą do pojawiania się lokalnych konfliktów. Widoczne także stało się odradzanie organizacji nacjonalistycznych zarówno w Białymstoku, jak i całym regionie.

Konflikty, sprzeczności, niezgodności są ważnymi, nieuniknionymi i powszechnymi zjawiskami życia społecznego. Jednym z podstawowych rodzajów konfliktów - widocznym w nowoczesnych i heterogenicznych kulturowo społeczeństwach i państwach - stał się konflikt etniczny. W sytuacji gdy wspólnotę europejską trawi kryzys jedności, pojawiły się silne ruchy odśrodkowe w wielu państwach (np. Hiszpania), idea wielokulturowości zdaje się ustępować powracającej tryumfalnie idei państwa narodowego, a państwa europejskie zapełniają się migrantami i uchodźcami o całkowicie odmiennej kulturze, musimy prowadzić, analizować i wyciągać wnioski z badań koncentrujących się na relacjach międzykulturowych (w tym konfliktach) i postrzeganiu "obcego" etnicznie, narodowo czy religijnie. W tej sytuacji należy zwrócić uwagę nie tylko na współpracę między kulturami, narodami i grupami etnicznymi, ale również na sytuacje konfliktowe, choćby po to, aby można było je przewidywać i kontrolować.

\section{Konflikty narodowo-etniczne oraz ich czynniki w województwie podlaskim}

Analiza konfliktów społecznym, dotarcie do i zrozumienie ich źródeł oraz sposobów ich rozwiązywania stały się częstymi tematami prac i badań naukowych. Problematyka konfliktów społecznych została dość dokładnie przeanalizowana przez takich klasyków socjologii, jak Ralf Dahrendorf $(1968,1972)$ czy Lewis Coser $(1964,1970)$. W tej pracy chciałbym skupić się na jednym z podstawowych rodzajów konfliktów, widocznym w nowoczesnych i heterogenicznych kulturowo społeczeństwach i państwach, jakim jest konflikt 
etniczny. Najczęściej uznaje się, że konflikty te można analizować przy pomocy tej samej aparatury pojęciowej, co wszelkie inne konflikty społeczne (Mucha, 2006, s. 291). Natomiast znaczenie społeczne badań prowadzonych nad konfliktami etnicznymi jest związane z tym, że większość dzisiejszych "gorących" i fizycznych konfliktów to konflikty, u których podnóży leży wrogość etniczna (Banton, 2000, ss. 481-485).

Termin konflikt etniczny nie jest jednoznacznie stosowany i rozumiany zarówno w języku potocznym, jak też w nauce. Stosuje się go nie tylko w celu oznaczenia różnych form starć i przejawów wrogość o podłożu etnicznym i kulturowym, z jakimi spotykamy się dosyć często w życiu społecznym, ale także w celu określenia różnych sytuacji konfliktotwórczych, które mogą, ale wcale nie muszą, prowadzić do otwartych i gorących konfliktów. Oczywiście należy podkreślić, że do powstawania, trwania i ujawniania się konfliktów etnicznych niezbędne są wyraźna świadomość i tożsamość etniczna, świadomość kulturowej odrębności poszczególnych grup, kontakt pomiędzy tymi grupami oraz odpowiednie środowisko społeczne i polityczne. Podobnie jak Józef Obrębski (1936, ss. 177-195) uważam, że jednym z podstawowych powodów pojawienia się tożsamości grupowej (w tym również etnicznej), silnego poczucia przynależności oraz odrębności są kontakty członka danej grupy z ludźmi należącymi do innej grupy i kultury. Poczucie reprezentacji grupy etnicznej, „etniczność” ukazuje się wtedy, gdy mamy do czynienia z kontaktem pomiędzy, co najmniej, dwiema różnymi grupami etnicznymi. W związku z tym zarówno krystalizowanie się tożsamości etnicznej, jak i związany z nią konflikt etniczny pojawiają się najczęściej w środowisku zróżnicowanym etnicznie i kulturowo. Bardzo ważne staje się w tym przypadku postrzeganie "obcego", a sam konflikt z grupą zewnętrzną wzmacnia tożsamość grupy wewnętrznej (Sumner, 1979). „Za konflikt etniczny sensu stricto uznać można taki ostateczny, gwałtowny rezultat opozycji międzygrupowej, którego stronami są narody (grupy etniczne) i w którym bardziej niż o posiadanie, władzę lub informację chodzi o tożsamość kulturową stron" (Kwaśniewski, 1994, s. 52).

W literaturze przedmiotu konflikt etniczny, mimo że opisywany często, nie ma jednej precyzyjnej definicji. Najczęściej definiuje się go poprzez określenie jego przyczyn albo przez podanie podmiotów biorących w nim udział. Czyli, w szerokim rozumieniu, konflikt etniczny należy postrzegać jako taki, który jest związany z obroną tożsamości narodowej lub jej atrybutów, a w innym przypadku, gdy jego stronami są narody, mniejszości narodowe lub grupy etniczne. Najczęściej opiera się on na sprzeczności interesów grupowych (kon- 
flikt interesów, system wrogich działań jednej grupy wobec innych lub przez kilka grup w stosunku do siebie nawzajem) oraz antagonizmie. „Konflikty etniczne dotyczą zwykle dóbr zbiorowych, a nie indywidualnych, dóbr niedających się, w przekonaniu stron konfliktu, podzielić. Takimi dobrami są: prawo do używania własnego języka, prawo do wierzeń i symboli religijnych, prawa i przywileje obywatelskie, posiadanie władzy na danym terytorium, grupowa dominacja gospodarcza czy prestiż grupy" (Mucha, 2005, s. 97). W związku z powyższym, zjawisk społecznych badanych i analizowanych jako konflikty etniczne jest bardzo wiele, najczęściej zalicza się do nich: wojny między narodami, grupami etnicznymi i plemionami, nacjonalizm i agresja oraz procesy narodotwórcze (w tym secesjonizm i separatyzm), działania zbiorowe o etnicznym podłożu i celu (np. obrona tożsamości narodowej), przesądy, stereotypy i dyskryminację etniczną, agresję w stosunku do etnicznych symboli grupowych, konflikt etniczny jako instrument w polityce czy rezultat zmian systemowych (por. Posern-Zieliński, 1996; Budyta-Budzyńska, 2010).

Należy w tym momencie zwrócić uwagę, że konflikty etniczne nie muszą być zdarzeniami pełnymi przemocy fizycznej, agresji czy po prostu wojnami. „Konflikt etniczny w znaczeniu behawioralnym (...) nie ogranicza się do bezpośredniej przemocy fizycznej przeciw osobom. Może on mieć charakter dyskryminacyjnych regulacji prawnych, podejmowanych przez grupę etniczną dominującą politycznie czy działań symbolicznych, w tym ataków na symbole grupowe" (Mucha, 2005, s. 98). Konflikty etniczne mogą więc polegać, czy odwoływać się do długotrwałego stanu napięcia, wrogości czy stosowaniu przemocy symbolicznej w postaci obraźliwych napisów czy haseł na murach bądź forach internetowych, dewastacji pamiątek, skrajnych wystąpieniach politycznych czy nacjonalistycznych marszy i wykrzykiwanych tam haseł. W artykule odwołuję się właśnie do takich sytuacji i stanu napięcia. Opisuję sytuacje konfliktowe, a nie w pełni gorące, fizyczne, behawioralne konflikty. Trzeba jednak zwrócić uwagę na to, że w różnych miejscach i czasie na bazie tych sytuacji, stanu napięcia, a następnie wrogości mogą powstać w pełni rozwinięcie "gorące" konflikty.

Chciałbym również zwrócić uwagę na fakt przemian wewnętrznych w regionie i Polsce, jak i zewnętrznych, które nastąpiły w ciągu ostatnich lat, a które miały widoczny wpływ na wzajemne stosunki przedstawicieli różnych narodowości, grup etnicznych i kultur w województwie podlaskim. W kontekście prowadzonych badań w województwie podlaskim uważam, że kończy się etap analizy struktury etnicznej mieszkańców z perspektywy społecznego ładu. Rzutuje na powyższe kilka czynników, które poddam krótkiej analizie. 
Pierwszym czynnikiem jest uzyskanie przez mniejszości dojrzałości i świadomości własnej podmiotowości. W tej sytuacji ład, który polegał na przymusowym dostosowywaniu się mniejszości do większości, przestaje odpowiadać warunkom i wystarczać. W przeszłości liczba konfliktów i spięć była mniejsza, a ich zasięg i widoczność słabła, gdyż członkowie mniejszości dobrowolnie asymilowali się do polskości. Tysiące przedstawicieli mniejszości białoruskiej, litewskiej czy ukraińskiej wyzbywali się swoich atrybutów kulturowych, aby stać się częścią większości. Była to najłatwiejsza i najszybsza droga umożliwiająca awans społeczny dla przedstawicieli tych grup. Brak konfliktu etnicznego w sensie behawioralnym nie musiał oznaczać, że mieliśmy faktycznie do czynienia $\mathrm{z}$ równym dostępem wszystkich grup etnicznych do zasobów ekonomicznych, politycznych czy symbolicznych na danym obszarze i w kraju. Brak konfliktów wynikał raczej z wymuszonej zgody grup upośledzonych na nierówne traktowane ich przez grupę dominującą. „Konflikt etniczny oznaczać więc może „postęp” w takim znaczeniu, że grupa, dotąd niedopuszczana do zasobów, odmawia akceptacji dominacji i podejmuje walkę. Symboliczna (i inna) agresja ze strony grupy dominującej przeciw grupie podporządkowanej wynikać może z nowego poczucia zagrożenia u tej pierwszej" (Mucha, 2005, s. 101). Obecnie, w kontekście kształtujących się społeczeństw liberalno-demokratycznych, upodmiotowieniu mniejszości, ten statut gorszości w większości przypadków obala. W sytuacji, gdy mają miejsce wydarzenia dawniej uznawane za normalne (np. asymilacja, narzucanie zdania większości czy przemoc symboliczna), obecnie mniejszości protestują, jawnie wyrażają swoje odmienne zdanie i niezadowolenie. Wobec tego konflikt etniczny możemy tratować jako „postęp”, istotny krok w rozwoju relacji etnicznych w społeczeństwie demokratycznym.

Drugim czynnikiem, który uważam za istotny, jest prowadzenie przez Polskę, ale również pozostałe kraje byłego bloku sowieckiego, innej polityki międzynarodowej, która nie stwarza mniejszościom narodowym szans na kontakt z macierzą. Ład na Podlasiu w przeszłości był warunkowany w znacznym stopniu polityką państwa polskiego. Państwo w tym przypadku jest bardzo ważnym aktorem na scenie konfliktów etnicznych. Może się starać zachować „neutralność etniczną”, co zresztą wśród państw Europy Zachodniej jest dzisiaj często praktykowane. Jednak polityka „nieingerencji” w konflikty etniczne może sama być czynnikiem stymulującym dla tych konfliktów. W związku z powyższym działania państwa mogą być jednym z najważniejszych czynników wywołujących mobilizację grup etnicznych, swoistym bodźcem zewnętrznym do działania. Państwo poprzez szereg swoich działań może ułatwiać lub utrudniać działania grup etnicznych oraz powodować ich 
mobilizację, jak i demobilizację (np. akcja „Wisła” czy cofnięcie dotacji państwowych na rozwój tożsamości mniejszościowych). Może wprost stanowić stronę konfliktu, wspierając czy reprezentując jedną, dominującą grupę etniczną. Należy w tym miejscu zwrócić uwagę na ciekawą relację większość - mniejszość w państwie narodowym, a mianowicie „wolność bowiem jest relacją społeczną: aby jedni mogli dysponować wolnością realizacji swoich celów, innym trzeba odebrać wolność stawiania oporu" (Bauman, 2013, s. 16).

Współcześnie z jednej strony obowiązujący, demokratyczny porządek prawny daje konkretne zasady i możliwości działań wszystkim grupom etnicznym i mniejszościowym, a z drugiej strony sytuacja polityki wewnętrznej, jak i międzynarodowej państwa Polskiego uległa widocznym komplikacjom. Polska w nurcie rozgrywek geopolitycznych występuje jako Państwo - Naród, nie dzieli się na części. W związku z takim podejściem Polska dziś nie jest zainteresowana mniejszościami, ich prawami i rozwojem. Działania ludzi i ich dobro ma być podporządkowane wizji państwa narodowego i dobru narodu, a nie dobru obywateli i ich szczęściu. Znacznie częściej występują również różnego typu napięcia na tle zarówno polityki bieżącej, jak i historycznej między Polską a Litwą, Rosją, Białorusią czy Ukrainą. To często powoduje chaos tożsamościowy, jest podłożem konfliktów, często działań „zaczepnych”, prowokacyjnych, zmiany stosunku i postaw wobec „innych” narodowościowo i etnicznie. Dodatkowo mniejszości nie są w stanie dzisiaj rozwijać swoich tożsamości narodowych poprzez proste kontakty z macierzami. Nie dostają i nie mają dużego zainteresowania ze strony Białorusi czy Ukrainy, a to sprawia, że głównie same, autonomicznie podejmują różne działania w celu zachowania swojej tożsamości i kultury.

Kolejnym ważnym czynnikiem wpływającym na pojawianie się sytuacji konfliktowych w regionie jest wzrost postaw narodowych w Polsce i Europie. $\mathrm{Z}$ jednej strony mamy do czynienia ze zmianą polityki wewnętrznej wielu państw (w tym Polski), a z drugiej z widocznym wzrostem postaw nacjonalistycznych wśród znaczniej części obywateli tych państw. W wielu społeczeństwach nastąpił powrót do idei szeroko rozumianego państwa narodowego, naród postrzegany jest jako ethnos (wspólnota etniczno-genealogiczna oparta na kulturze i prawie krwi (ius sanguinis), a nie jako demos (wspólnota obywateli). Nadto efektem ubocznym wizji silnego państwa narodowego są pojawiające się postawy i zachowania głoszące wyższość jednego narodu nad innymi, uzasadnienie stosowania przemocy w narodowych wartościach i racji czy dyskryminowanie przedstawicieli innych narodów. „Etniczne państwo narodowe jest koncepcją ekskluzywną ograniczającą możliwość party- 
cypacji politycznej, ekonomicznej i kulturowej w funkcjonowaniu państwa dla ludności odmiennej kulturowo. Etniczne państwo narodowe ogranicza autonomiczność społeczno-kulturową mieszkańców pograniczy, a wspiera działania włączające je przez procesy asymilacyjne do narodu dominującego" (Sadowski, 2019, s. 62). Dlatego często w państwie narodowym pojawiają się wśród mniejszości postawy niepewności, braku bezpieczeństwa, strachu w związku z kultywowaniem własnej tradycji i kultury, a samo państwo narodowe może zmniejszać autonomię kulturową mniejszości, ograniczać dotacje i współdziałanie. Jednym z przykładów takiego działania ze strony rządu polskiego jest ograniczenie wydatków budżetu państwa na rok 2020 dla mniejszości narodowych i etnicznych na ochronę, zachowanie i rozwój tożsamości kulturowej o 30\%. Jest to pierwszy taki przypadek w historii Polski od 1989 roku. Przedstawiciele wszystkich mniejszości podczas Komisji Wspólnej Rządu i Mniejszości Narodowych i Etnicznych apelowali do rządu by nie zmniejszać środków na tę działalność (Myszka, 2019).

Ważnym czynnikiem konfliktogennym, związanym z etnicznością i pograniczem, jest również narastający odsetek ludzi zawiedzionych dotychczasowymi kontaktami z Zachodem, a co za tym idzie, wybudzanie się postaw nacjonalistycznych. Te narastające w ostatnich latach tendencje wydają się szczególnie widoczne wśród ludzi młodych. Przyczyny tego faktu należałoby zbadać, ale zapewne korzeni należy szukać w braku poczucia bezpieczeństwa, istnieniu silnego wykluczenia i rozwarstwienia społecznego, potrzeby identyfikacji, zwłaszcza wśród młodych, czy rewizjonizmu historycznego i tworzenia nowej symboliki narodowej. To młodzi są członkami skrajnych organizacji narodowych, odwołujących się do treści ksenofobicznych i eurosceptycznych, takich jak ONR (Obóz Narodowo-Radykalny) czy Młodzież Wszechpolska. Głównymi wyborcami sił populistycznych w Polskim parlamencie (Kukiz 15 i Konfederacja) są ludzie w przedziale wiekowym 18-29 lat. To dzięki nim po raz pierwszy w historii III Rzeczpospolitej do Sejmu wprowadzono siły skrajnej prawicy. Dodatkowo młodzi wydają się rozczarowani konsumpcją i zaawansowanym kapitalizmem Zachodu. Oczywiście te spostrzeżenia należy poddać wnikliwym badaniom, których obecnie brak.

\section{Przykłady konfliktów etnicznych/sytuacji konfliktowych w województwie podlaskim}

Polska w ciągu niemal 30 lat demokracji wprowadziła szereg regulacji wewnętrznych w zakresie ustawodawstwa (podstawowym aktem $\mathrm{w}$ tym zakresie 
jest Ustawa o mniejszościach narodowych i etnicznych oraz o języku regionalnym z 2005 roku) oraz ratyfikowała wiele dokumentów międzynarodowych, takich jak Konwencja Ramowa o ochronie mniejszości narodowych czy Europejska Karta Języków Regionalnych lub Mniejszościowych. W ten sposób dano mniejszościom prawa i możliwości działania, obrony oraz rozwoju swojego dziedzictwa kulturowego oraz tożsamości.

W województwie podlaskim wystąpił między innymi konflikt o zasoby, które umożliwiają rozwój własnej kultury i tożsamości. Ta sytuacja konfliktowa pojawiła się pomiędzy mniejszością litewską a większością polską (reprezentowaną przez władze gminne i państwowe). Problem powstał i rozwijał się latami w kontekście szkolnictwa mniejszościowego, utrzymania sieci litewskich szkół i ich finansowania. Z czasem nabierał rozgłosu i otarł się nawet o wzajemne stosunki międzypaństwowe polsko-litewskie. O stanie napięcia na pograniczu polsko-litewskim oraz o możliwości wystąpienia konfliktów na tle etnicznym (w różnych wymiarach) pisała m.in. Małgorzata Bieńkowska (2007, ss. 89-92).

Liczebność samej mniejszości litewskiej w Polsce, według ostatniego spisu powszechnego (2011 rok), sięga 8 tys. osób. Liderzy organizacji tej społeczności mówią o kilkunastu tysiącach Litwinów w Polsce, głównie skupionych w gminie Puńsk oraz na Sejneńszczyźnie w województwie podlaskim. Jeszcze we wrześniu 2012 roku nauka języka litewskiego była prowadzona w 19 placówkach w regionie, dzisiaj ich liczba spadła o ponad 70\% (PAP, 2019). Oficjalnym powodem była mała liczba uczniów w szkołach wiejskich. $\mathrm{Na}$ przykład radni gminy Puńsk tylko w 2013 roku zlikwidowali trzy wiejskie szkoły z litewskich językiem nauczania w Widugierach, Przystawańcach i Nowinikach. Tym samym zdecydowano o przeniesieniu i skoncentrowaniu oświaty litewskiej w Polsce w dwóch największych ośrodkach związanych z tą mniejszością, czyli w Sejnach i Puńsku.

Środowiska związane z organizacjami mniejszości litewskiej są niezadowolone i zaniepokojone decyzjami o zamykaniu szkół. Przedstawiciele Wspólnoty Litewskiej w Polsce mówili o „czarnym dniu” oświaty litewskiej w Polsce i liczyli na pomoc ze strony ministra spraw zagranicznych Litwy Linasa Linkeviciusa oraz pani prezydent Dali Grybauskaite. Minister spraw zagranicznych stwierdził: „To egzekwujcie od swej władzy, żeby nie zamykała. Dlaczego nie żądacie? U nas Polacy stawiają żądania..." (Pieszko, 2013), natomiast Pani prezydent wyraziła opinię, że władze polskie powinny wziąć pod uwagę, że na Litwie małe szkoły są utrzymywane. Mimo mediacji konflikt nie został pozytywnie rozwiązany, a władze polskie odpowiedziały, że jest to we- 
wnętrzna sprawa władz lokalnych, a w Polsce szkoły mniejszości są znacznie lepiej finansowanie niż na Litwie.

Inną odsłoną tego konfliktu był spór pomiędzy samorządem miasta Sejny a Fundacją im. biskupa Antanasa Baranauskasa. Dom Litewski w Sejnach prowadzi niepubliczną szkołę „Žiburys”. Miasto latami przekazywało mniejszą niż przewiduje prawo subwencję oświatową, chociaż otrzymywało na ten cel odpowiednią subwencję rządową, na co wskazała już w 2015 roku Regionalna Izba Obrachunkowa. Jednak samorząd miasta, zamiast prawidłowo rozliczać subwencję i zwrócić Fundacji należne jej pieniądze, doniósł na Fundację do prokuratury, oskarżając ją o oszustwo związane z liczbą dzieci uczęszczających do litewskiej szkoły i przedszkola. Prokuratura nie znalazła żadnych dowodów na poparcie tych zarzutów i cała sprawa skończyła się ugodą w sądzie zawartą we wrześniu 2017 roku. Fundacja prowadząca szkołę i przedszkole otrzyma od miasta $2 \mathrm{mln} 220$ tys. zł w ratach rozłożonych na lata 2018-2022 (sejny.net, 2017).

Kolejną sytuacją konfliktową, jaka pojawiła się w ostatnich latach, jest ta związana z przemocą symboliczną i powtarzającymi się dewastacjami historycznych i religijnych pamiątek, symboli związanych z tatarską grupą etniczną.

Obecnie nie wiadomo, ilu dokładnie Tatarów zamieszkuje na terenie Polski. Według danych narodowego spisu powszechnego z roku 2011 narodowość tatarską zadeklarowało 1916 osób, z czego 665 jako jedyną (GUS, 2013). Należy jednak nadmienić, że najczęściej sami przedstawiciele tej grupy etnicznej, jak i badacze, mówią o około czterech tysiącach tatarów w Polsce. Pewnym natomiast jest, że większość z nich pochodzi z lub ciągle zamieszkuje w województwie podlaskim w okolicach miejscowości Kruszyniany. Osadnictwo tatarskie na ziemiach Wielkiego Księstwa Litewskiego oraz Korony Polskiej sięga XIV wieku. Najczęściej byli to bardzo chętnie przyjmowani przez władców Polski i Litwy uchodźcy polityczni, którzy zobowiązywali się do służby wojskowej. Nazywano ich Lipkami lub Muślinami. Ludność ta, jak zaznaczają historycy, od XV wieku stopniowo zatracała swój język ojczysty i ulegała szybkiej asymilacji. W dzisiejszym województwie podlaskim pojawili się za sprawą Jana III Sobieskiego, który 12 marca 1679 roku nadał Tatarom kilka wsi, w tym największą były Kruszyniany (około 45 rodzin) (Borawski i Dubiński, 1986). Od tamtej pory ludność tatarska na stałe wpisała się w krajobraz etniczny terenów, które dzisiaj nazywamy województwem podlaskim. Mimo wspomnianej wyżej asymilacji językowej są dzisiaj jedyną autochtoniczną muzułmańską mniejszością na terenie Polski. 
W tym kontekście niezmiernie zaskakuje sytuacja konfliktu związanego z pojawiającymi się dewastacjami najważniejszych symboli etnicznych Tatarów, czyli religijnych zabytków we wsi Kruszyniany. Jest to przykład sytuacji konfliktowej związanej z atakiem/obroną symboli etnicznych. Najczęściej celem takich działa jest pozbawienie grupy symboli i pamiątek, które łączą z historią i kulturą przodków, a tym samym niwelowanie różnić w krajobrazie etnicznym danego regionu (Budyta-Budzyńska, 2010, s. 229).

Największy akt wandalizmu zdarzył się podczas apogeum kryzysu migracyjnego, który wywoływał w Polsce duże poczucie zagrożenia i niechęci wobec ludności muzułmańskiej. 29 czerwca 2014 w nocy z soboty na niedzielę nieznani sprawcy namalowali sprayem gryzmoły i rysunki na zabytkowym meczecie w Kruszynianach oraz na płytach nagrobnych w starej i nowej części tamtejszego mizaru - muzułmańskiego cmentarza (por. fotografie 1 i 2). Ze wstępnych oględzin tych zabytkowych miejsc wynika, że na meczecie pomarańczową farbą na drzwiach wejściowych namalowano znak „X”, jakby przekreślający drzwi. Na ścianach zewnętrznych namalowano też m.in. symbol Polski Walczącej, świnię, są też namalowane fale na ścianach, które w niektórych miejscach zahaczają także o dolną część okien świątyni. $\mathrm{Na}$ znajdującym się obok meczetu pamiątkowym kamieniu z napisem „Pomnik historii” - bo taki tytuł mają kruszyniański meczet i Mizar - namalowano coś, co przypomina trupią czaszkę i skrzyżowane kości piszczelowe. Z informacji policji wynika również, że na mizarze pobazgranych jest około 30 płyt nagrobnych na 28 miejscach pochówku, przede wszystkim w głównej alei cmentarza. W ciągu kolejny miesięcy zdarzały się też inne incydenty, m.in. zakłócanie święta czy podpalenie traw obok meczetu (PAP, 2014).

Przewodniczący Muzułmańskiej Gminy Wyznaniowej w Kruszynianach Bronisław Talkowski zaznacza, że nie przypomina sobie żadnego konfliktu ze społecznością lokalną. Deklaruje wzajemny szacunek i współpracę. Za sprawców uważa nacjonalistów chcących zastraszyć Tatarów, niestety sprawców nie wykryto (Szewczyk, 2018). Obecnie meczet jest monitorowany. Niesmak tych wydarzeń podkreśla fakt, że dzisiaj Tatarom w Polsce bliżej kulturowo do Polaków chrześcijan niż arabów czy muzułmanów z Afryki oraz Bliskiego Wschodu. Tatarzy już kilka wieków temu zatracili swój język ojczysty, nie mają też charakterystycznych dla siebie strojów, chyba że za takowe uznać te, które sprowadzają od Tatarów mieszkających na Krymie lub w Tatarstanie. Na przestrzeni wieków bardzo głęboko nasiąkli polską kulturą. Z tego powodu islam i związane z nim obyczaje są czynnikami, które najbardziej wyróżniają Tatarów spośród społeczeństwa polskiego. W tym przypadku tak na prawdę nie da się 
oddzielić etniczności od religijności. Tatarzy oczywiście są muzułmanami albo bardzo zasymilowanymi do kultury europejskiej (Rusanowska, 2015, s. 22).

Fot. 1. Zdewastowana ściana meczetu w Kruszynianach

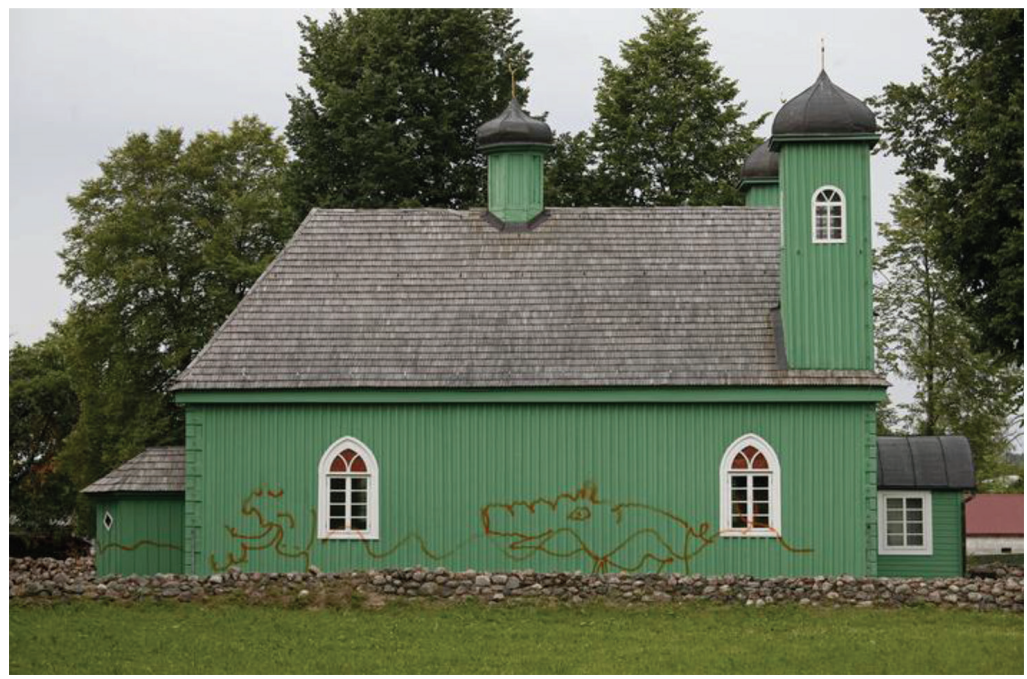

Źródło: Polska Agencja Prasowa. Autor: Artur Reszko.

Fot. 2. Zdewastowana brama mizaru - muzułmańskiego cmentarza w Kruszynianach. Wandale wymalowali na niej symbol Polski Walczącej

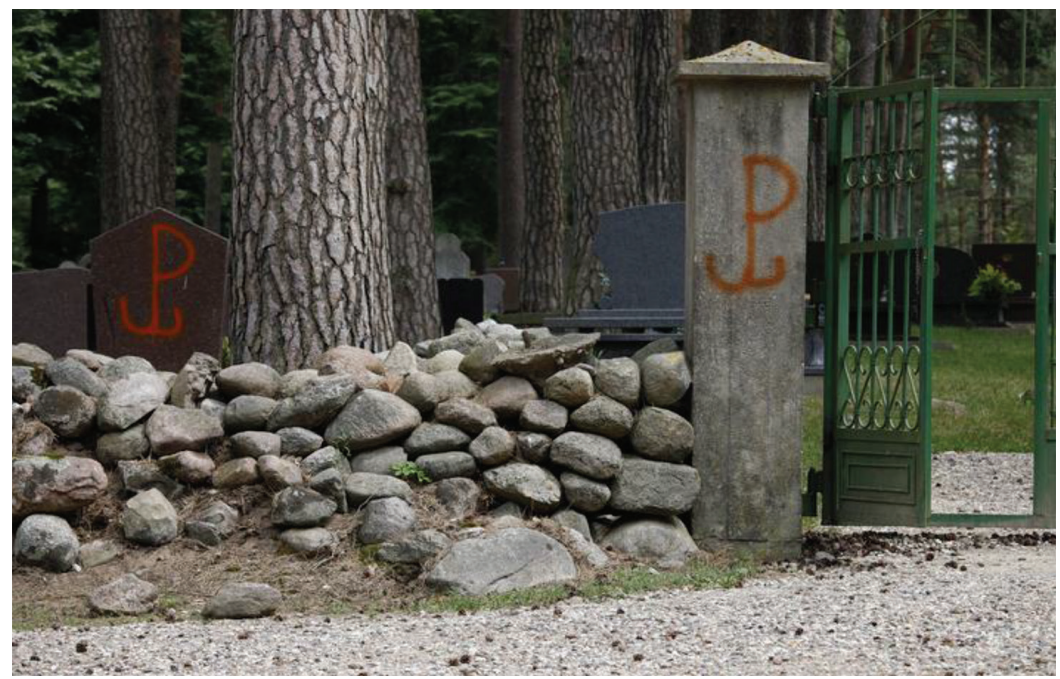

Źródło: Polska Agencja Prasowa. Autor: Artur Reszko. 
Kolejnym przykładem konfliktu większość-mniejszość, pełnym przemocy symbolicznej i prowokacji, są powodujące bardzo duże napięcia w społeczności lokalnej, organizowane przez skrajnie prawicowe organizacje marsze i zgromadzenia. Konflikt ten dotyczy historii, pamięci i symboli, jakie przyjmuje większość, a które stoją w sprzeczności z pamięcią historyczną mniejszości. W kontekście konfliktu pamięci problem ten podejmowała Anna Mo$\operatorname{roz}(2016$, ss. 61-91).

Od lutego 2015 roku w Hajnówce cyklicznie organizowany jest „Marsz żołnierzy wyklętych” (por. fotografię 3). Za marsz odpowiada Obóz Narodowo-Radykalny oraz stowarzyszenie Narodowa Hajnówka. Zgromadzenie budzi co roku wielkie emocje i sprzeciw lokalnej społeczności, ze względu na to, że ma głównie upamiętniać kapitana Romualda Rajsa „Burego”, którego oddział ponad 70 lat temu dokonał pacyfikacji pięciu wsi zamieszkanych przez ludność białoruską wyznania prawosławnego. Zimą 1946 roku koło Bielska Podlaskiego spalono wsie: Zanie, Zaleszany, Końcowizna, Szpaki i Wólka Wygonowska, mordując w sumie 79 osób, w tym kobiety i dzieci. W tej sytuacji stawianie jako przykład żołnierza wyklętego i bohatera kapitana „Burego” oraz czczenie go wśród miejscowej prawosławnej społeczności białoruskiej zakrawa na ponury żart oraz bezpośrednią prowokację do otwartego konfliktu. Na facebookowym koncie białostockiego oddziału Obozu Narodowo-Radykalnego widniał następujący wpis zachęcający do udziału w marszu: „Nie wyobrażamy sobie, żeby ktoś ze środowiska patriotycznego nie jechał na sobotni marsz do Hajnówki. Łatwo jest się lansować w koszulkach z Wyklętymi, łatwo słuchać piosenek Tadka i łatwo jest uczestniczyć w różnych wydarzeniach, np. w Białymstoku. Hajnówka to teren, gdzie do dziś funkcjonują komunistyczne kłamstwa dotyczące Niezłomnych, dlatego obowiązkiem każdego z nas jest czcić tam Ich pamięć! Kto nie jedzie z lenistwa, albo ze strachu przed lewactwem, ten jest cipa, a nie patriota-nacjonalista!" (Kurier Poranny 2016). Na portalu Narodowej Hajnówki nawoływano: „Łatwo jest manifestować w miastach, gdzie władze i lokalna ludność są w większości przychylne tematyce Żołnierzy Wyklętych. Czczenie pamięci niezłomnych w miejscach, gdzie propaganda komunistyczna funkcjonuje dalej, wymaga hartu i odwagi" (Kurier Poranny 2016). Podczas samego marszu skandowano takie hasła, jak: „Bury nasz bohater”, „Idą nacjonaliści” czy „Raz sierpem, raz młotem czerwoną hołotę”. W marszu biorą udział również politycy związani wcześniej z partią „Kukiz 15”, dzisiaj „Konfederacją”, a nawet z Prawem i Sprawiedliwością (np. poseł Adam Andruszkiewicz). W pierwszym marszu w 2015 roku brali udział harcerze, a organizatorzy ogłosili, że marsz objął patronatem prezydent Andrzej Duda (co ostatecznie okazało się nieprawdą). 
Fot. 3. I Marsz Żołnierzy Wyklętych w Hajnówce

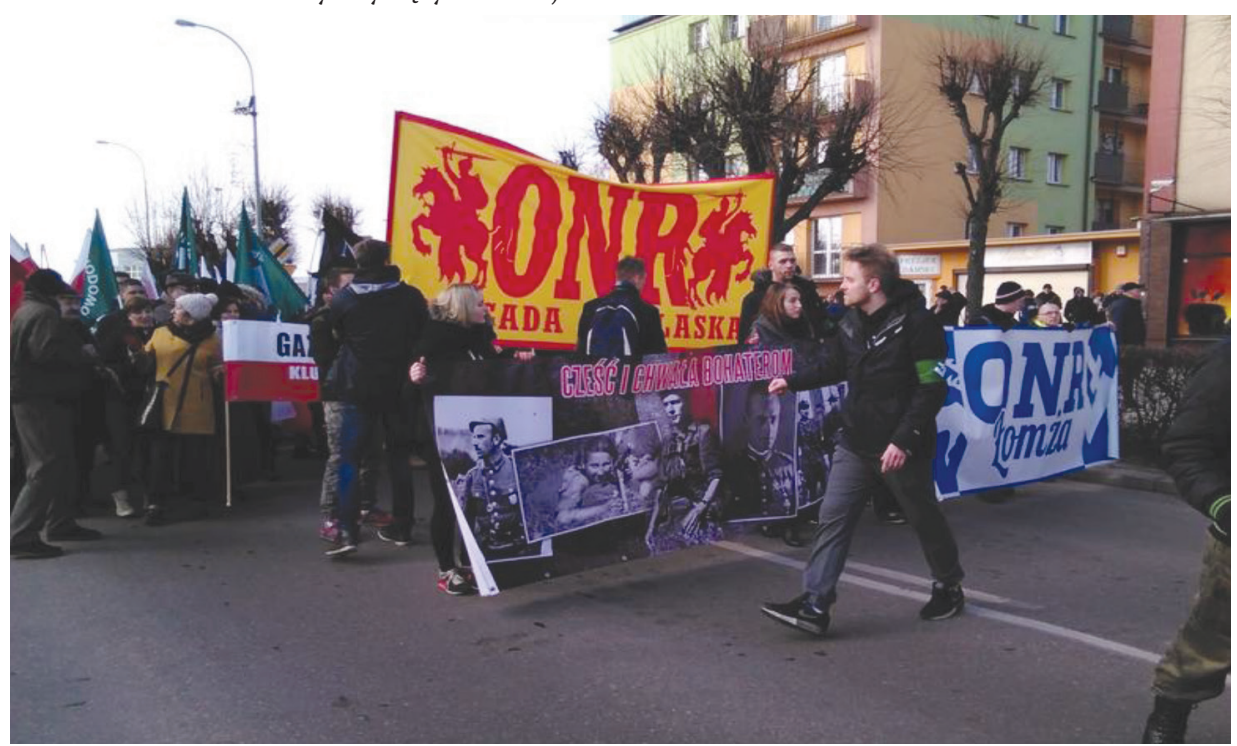

Źródło: Kurier Poranny. Autor: Andrzej Zdanowicz.

Zdjęcie 3. Kontrmanifestacja mieszkańców Hajnówki

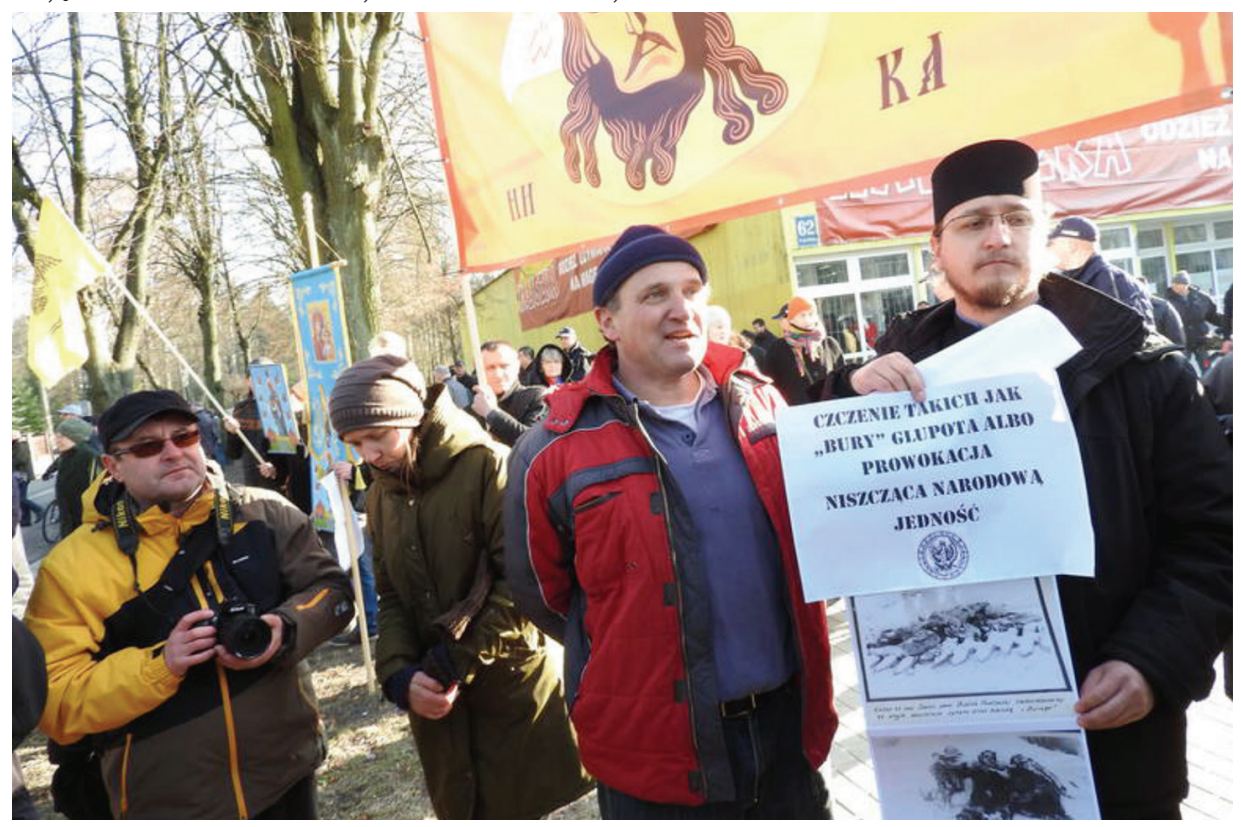

Źródło: Kurier Poranny. Autor: Andrzej Zdanowicz. 
Marsz od początku wzbudził sprzeciw miejscowej ludności. Prezydent Hajnówki oraz rada miasta uznały marsz za prowokację, która ma wywołać nienawiść i podziały na tle religijnym i narodowościowym, i co roku wydają zakaz marszu, który jest następnie uchylany przez sąd. Mieszkańcy Hajnówki co roku zbierają się i organizują kontrmanifestacje, próbując zablokować marsz.

W tym miejscu należy dodać, że w ostatnich latach nastąpił istotny zwrot w stosunku samego państwa polskiego w ocenie działań Romualda Rajsa „Burego". Jeszcze w 2005 roku pion śledczy IPN, umarzając śledztwo w sprawie działań „Burego”, podkreślał: „Reasumując, zabójstwa i usiłowania zabójstwa tych osób należy rozpatrywać jako zmierzające do wyniszczenia części tej grupy narodowej i religijnej, a zatem należące do zbrodni ludobójstwa" (PAP IAR, 2019). Natomiast w marcu 2019 roku IPN wydał komunikat (niepodpisany), w którym podważa ustalenia pionu śledczego z lat 2002-2005, oraz poinformował, że w świetle najnowszych badań kapitan Romuald Rajs pseudonim „Bury” i kierowana przez niego 3. Wileńska Brygada Narodowego Zjednoczenia Wojskowego nie dopuścili się ludobójstwa (PAP IAR, 2019). Jest to, moim zdaniem, kolejny przykład na zwrot państwa polskiego w kierunku państwa narodowego, które promuje swoją wizję historii, pamięci i symbole. Niestety, w tym przypadku wiąże się to nie tylko z włączaniem, czy nawet asymilowaniem mniejszości, ale głównie z ich wyłączaniem i ignorowaniem. „Państwo narodowe wiąże się nie tylko z włączaniem, ale także z wyłączaniem innych, obcych, wrogów, niepotrzebnych itp. Pogranicza systematycznie „przypominają o kłopotach, nierównościach kulturowych związanych z wdrażaniem do praktyki zasad funkcjonowania narodowego państwa" (Sadowski, 2019, s. 61).

W artykule, ze względów merytorycznych i objętościowych, koncentruję się jedynie na konfliktach większość-mniejszość. Należy jednak zaznaczyć, że w województwie podlaskim mamy również do czynienia z konfliktem o podłożu etnicznym i kulturowym, który z punktu widzenia badacza tożsamości narodowo-etnicznej i jej przemian jest szczególnie interesujący (przemiany tożsamości mniejszości ukraińskiej w województwie podlaskim opisuję w swojej książce „Ukraińcy Podlasia. Dylematy tożsamościowe” (Nikitorowicz, 2014). Jest to swoisty konflikt „o dusze” pomiędzy mniejszością białoruską a ukraińską w regionie, który zamierzam opisać w innej pracy.

\section{Podsumowanie}

Sytuacja heterogeniczności kulturowej województwa podlaskiego daje szczególne możliwości dla pojawienia się w regionie tolerancji, współpracy 
i wzajemnego poszanowania, ale również sytuacji konfliktowych pomiędzy poszczególnymi zbiorowościami czy nawet „gorącego” konfliktu narodowo-etnicznego. Wydaje się, że w obecnej sytuacji kształtowanie się początkowo ukrytych, a następnie całkowicie jawnych konfliktów na tle odmienności kulturowej i etnicznej jest nieuniknione. Uważam, że konflikty narodowo-etniczne w regionie (z przyczyn, które wymieniłem w artykule) będą pojawiać się coraz częściej, a problemem i zadaniem jest to, aby je odpowiednio szybko rozpoznawać i kontrolować. Dzisiejsze mniejszości narodowe i etniczne nie są tymi samymi grupami, z którymi państwo polskie miało do czynienia w latach 80. czy 90. XX wieku. Rozwinęły swoją świadomość, tożsamość, przywiązanie i dumę z kultury i historii, a w połączeniu z uzyskanymi prawami, pełną podmiotowość. Z drugiej strony mamy coraz silniej kreowaną i wprowadzaną ideologię państwa narodowego, które chce narzucać wartości, symbole i swoją pamięć historyczną. Obserwacja zróżnicowanego etnicznie i kulturowo pogranicza jest w tym przypadku szczególnie istotna, gdyż staje się ono swoistym przykładem tego, w jakim kierunku mogą podążać relacje międzykulturowe i etniczne w pozostałych częściach kraju i społeczeństwa. Pograniczność, związane z nim aspekty społeczne, postrzeganie „obcości” i konflikty, przestaje być domeną wyłącznie styku państw narodowych czy regionów, a staje się zjawiskiem powszechnym, występującym coraz częściej w dużych miastach całej Polski. Pogranicze w tym przypadku przenosi się na poziom sąsiadujących ze sobą wielu różnych grup etnicznych, narodowych, religijnych czy kulturowych (Krzysztofek, 2001).

\section{Bibliografia}

Awramiuk-Godun, A. 2013. Rozmieszczenie obiektów sakralnych jako kryterium wyznaczania zasięgu krajobrazu pogranicza kulturowego. Krajobrazy Pogranicza Kulturowego. 19, ss. 62-72.

Bauman, Z. 2013. Kultura jako praxis. Warszawa: PWN.

Banton, M. 2000. Ethnic Conflict. Sociology. 3 (34), pp. 481-498.

Barwiński, M. 2002. Podlasie jako region pogranicza. Studia z Geografii Politycznej i Historycznej. 3, ss. 281-306.

Bieńkowska, M. 2007. Polacy - Litwini - Białorusini. Przemiany stosunków etnicznych na pótnocno-wschodnim pograniczu Polski. Białystok: Wydawnictwo Uniwersytetu w Białymstoku.

Borawski, P. i Dubiński, A. 1986. Tatarzy polscy: dzieje, obrzędy, legendy, tradycje. Warszawa: Iskry. 
Budyta-Budzyńska, M. 2010. Socjologia narodu i konfliktów etnicznych. Warszawa: PWN.

Coser, L.A. 1964. The Functions of Social Conflict. New York: The Free Press.

Coser, L.A. 1970. Continuities in the Study of Social Conflict. New York: The Free Press.

Dahrendorf, R. 1968. Essays in the Theory of Society. London: Routledge and Kegan Paul.

Dahrendorf, R. 1972. Class and Class Conflict in Industrial Society. London: Routledge and Kegan Paul.

IPN podważyt wyniki śledztwa ws. Romualda Rajsa „Burego”, 2019, PAP IAR, tvp.info. https://www.tvp.info/41693891/ipn-podwazyl-wyniki-sledztwa-ws-romualda-rajsa-burego (20.09.2019).

Kosiedowski, W. i Słowińska, B. 2009. Podstawowe zagadnienia współpracy trans granicznej w warunkach integracji Europu Środkowo-Wschodniej z Unią Europejską. W: Kosiedowski, W. red. Pogranicze $w$ trakcie przemian. Rozwój i wspótpraca trans graniczna regionów Polski Wschodniej i państw sasiednich $w$ kontekście integracji Europy. Toruń: UMK, ss. 27$-49$.

Krzysztofek, K. 2001. Kulturowe źródła konfliktów w Europie Środkowej i Wschodniej. W: Helnarski, S. red. Nacjonalizm. Konflikty narodowościowe w Europie Środkowej $i$ Wschodniej. Toruń: Wydawnictwo Adam Marszałek, ss. 77-87.

Kruszyniany: dewastacja meczetu i cmentarza muzutmańskiego. „To byto przemyślane działanie” 2014. PAP, „polskieradio.pl”. https://www.polskieradio.pl/5/3/Artykul/1164797,Kruszyniany-dewastacja-meczetu-i-cmentarza-muzulmanskiego-To-bylo-przemyslane-dzialanie (4.11.2019).

Kwaśniewski, K. 1994. Konflikt etniczny. Sprawy Narodowościowe. 2, ss. 39-54 .

Ludność stan i struktura demograficzno-społeczna. 2013. Narodowy Spis Powszechny Ludności i Mieszkań 2011. Warszawa: Główny Urząd Statystyczny, ss. 89-90.

Moroz, A. 2016. Konflikt pamięci na pograniczu polsko-białoruskim na przykładzie działalności Romualda Rajsa ps. „Bury”. Studia z Geografii Politycznej i Historycznej. 5, ss. 61-91.

Mucha, J. 2005. Oblicza etniczności. Studia teoretyczne i empiryczne. Kraków: Zakład Wydawniczy „Nomos”.

Mucha, J. 2006. Przyczynek do analizy stosunków etnicznych. Stosunki między aktorami zbiorowymi a ład etniczny. W: Flis, A. red. Stawanie sie 
społeczeństwa: szkice ofiarowane Piotrowi Sztompce z okazji 40-lecia pracy naukowej. Kraków: „Universitas”, ss. 283-304.

Myszka, L. 2019. PiS oszczędza na mniejszościach narodowych i etnicznych. https://opowiecie.info/pis-oszczedza-mniejszosciach-narodowych-etnicznych/ (3.11.2019).

Nikitorowicz, A. 2014. Ukraińcy Podlasia. Dylematy tożsamościowe. Kraków: Zakład Wydawniczy „Nomos”.

Nikitorowicz, J. 1995. Pogranicze. Tożsamość. Edukacja międzykulturowa. Białystok: Wydawnictwo Uniwersyteckie „Trans Humana”.

Nikitorowicz, J. 2017. Etnopedagogika w kontekście wielokulturowości i ustawicznie kształtującej się tożsamości. Kraków: Oficyna Wydawnicza „Impuls".

Obrębski, J. 1936. Problem grup etnicznych w etnologii i jego socjologiczne ujęcie. Przeglad Socjologiczny. IV (3-4), ss. 177-195.

Pieszko, A. 2013. Zamykanie szkół: w Puńsku inaczej niż na Wileńszczyźnie? Kurier Wileński. https://kurierwilenski.lt/2013/02/27/zamykanie-szkol-w-punsku-inaczej-niz-na-wilenszczyznie/ (4.09.2019).

Posern-Zieliński, A. 1996. Konflikt etniczny w sytuacji imigracyjnej. W: Kabzińska-Stawarz, I. i Szynkiewicz, S. red. Konflikty etniczne. Warszawa: IAiE PAN, ss. 38-54.

Rusanowska, I. 2015. Wychowanie i kształcenie w muzułmańsko-chrześcijańskich rodzinach Tatarów polskich. Wrocław: Agencja Wydawcznicza „Argi" s.c.

Sadowski, A. 2019. Społeczeństwo wielokulturowe z perspektywy pogranicza. Kraków: Zakład Wydawniczy „Nomos”.

Sumner, W.G. 1979. Folkways and Mores. New York: Schocken Books.

Szczepański, M. i Śliz, A. 2014. Pogranicza w perspektywie socjologicznej. Pogranicze. Polish Borderlands Studies. 2 (1), ss. 52-53.

Szewczyk, P. 2018. Polscy Tatarzy: walczyliśmy u boku Sobieskiego. Dziś w Polsce niszczą nam meczety. Newsweek Polska. https://www.newsweek. $\mathrm{pl} /$ polska/meczet-kruszyniany-tatarzy-w-polsce-dewastacja-newsweekpl/ sy9h9yd\#articleGallery (16.10.2019).

Szkoła Žiburys otrzyma należne pieniądze. 2017. sejny.net. https://sejny.net/ artykul/szkola-iburys-otrzyma/563110 (13.09.2019).

Szkolnictwo litewskie w Polsce tylko w dużych placówkach. 2013. PAP, „portalsamorządowy.pl". https://www.portalsamorzadowy.pl/edukacja/szkolnictwo-litewskie-w-polsce-tylko-w-duzych-placowkach,45894.html (6.09.2019). 


\title{
National and ethnic conflicts in the communities of cultural borderland in the Podlasie Voivodeship
}

\begin{abstract}
The article presents a discussion on the conflicts of a national and ethnic origin that takes place in recent years among the borderland communities in Podlaskie Voivodeship. The author lists a number of internal and external factors that affect the occurrence of an increased number of ethnic-national conflict situations in the north-eastern borderland of Poland. He points out that the emerging conflicts do not mean a weakened position of ethnic and national minorities. The author presents some of the conflicts, emphasizing the increased awareness of defending one's values.
\end{abstract}

Keywords: national and ethnic conflict, borderland, minorities

Translated by Andrzej Nikitorowicz 